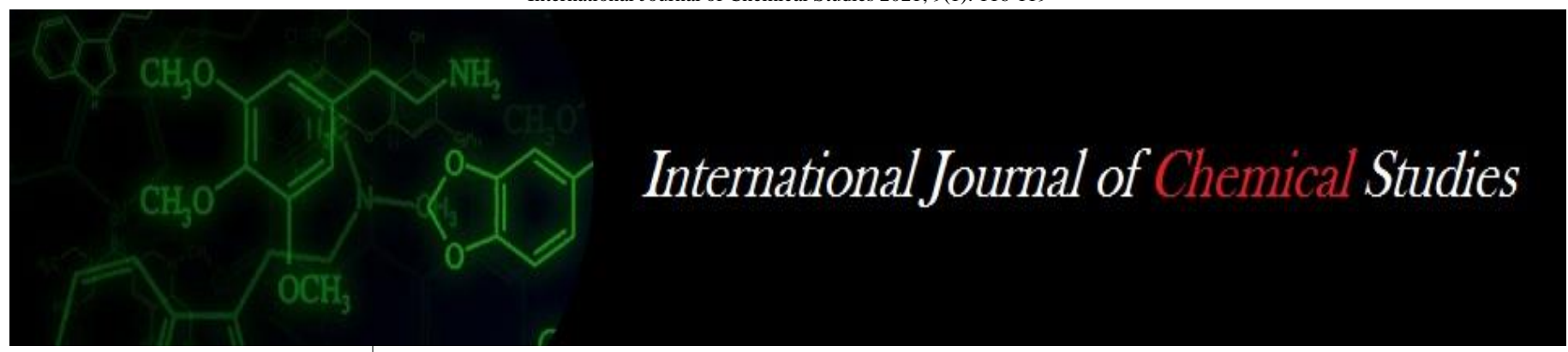

P-ISSN: 2349-8528

E-ISSN: 2321-4902

www.chemijournal.com

IJCS 2021; 9(1): 116-119

(C) 2021 IJCS

Received: 21-10-2020

Accepted: 03-12-2020

Keshab Debnath

M.V.Sc., Scholar, Department of

Livestock Products Technology, College

of Veterinary Sciences \& Animal

Husbandry, Central A ricult

University, Aizawl, Mizoram, India

\section{Pragati Hazarika}

Assistant Professor, Department of

Livestock Products Technology, College

of Veterinary Sciences \& Animal

Husbandry, Central Agricultural

University, Aizawl, Mizoram, India

Devajani Deka

Assistant Professor, Department of

Asistant Professo

Epidemiology, College of Veterinary

Sciences \& Animal Husbandry, Central

Agricultural University, Aizawl,

Mizoram, India

\section{AK Samanta}

Professor, Department of Animal

Nutrition, College of Veterinary Sciences

\& Animal Husbandry, Central

Agricultural University, Aizawl,

Mizoram, India

Anannya Das

M.V.Sc., Scholar, Department of

Livestock Products Technology, College

of Veterinary Sciences \& Animal

Husbandry, Central Agricultura

University, Aizawl, Mizoram, India

\section{Sandeep Kumar}

M.V. Sc., Scholar, Department of

Livestock Products Technology, College

of Veterinary Sciences \& Animal

Husbandry, Central Agricultural

University, Aizawl, Mizoram, India

Saifur Rahaman

M.V. Sc., Scholar, Department of Livestock Products Technology, College

of Veterinary Sciences \& Animal

Husbandry, Central Agricultural

University, Aizawl, Mizoram, India

Santanu Nath

M.V. Sc., Scholar, Department of

Livestock Products Technology, College

of Veterinary Sciences \& Animal

Husbandry, Central Agricultural

University, Aizawl, Mizoram, India

\section{Corresponding Author:}

Keshab Debnath

M.V.Sc., Scholar, Department of

Livestock Products Technology, College

of Veterinary Sciences \& Animal

Husbandry, Central Agricultura

University, Aizawl, Mizoram. India

\section{Use of apple pulp powder and pomegranate seed powder on extended storage of low fat emulsion pork sausage}

\author{
Keshab Debnath, Pragati Hazarika, Devajani Deka, AK Samanta, \\ Anannya Das, Sandeep Kumar, Saifur Rahaman and Santanu Nath
}

DOI: $\underline{\text { htps://doi.org/10.22271/chemi.2021.v9.i1b.11215 }}$

\begin{abstract}
Low fat pork sausage was developed with incorporation of olive oil, dried apple pulp and pomegranate seed powder. Shelf life was studied at $4 \pm 1{ }^{\circ} \mathrm{C}$ for 12 days. Proximate composition and sensory attributes were analyzed during the storage period. Average values observed for traditional pork sausage (T1) were moisture $-47.9 \%$, protein $-24.72 \%$, fat $-25.18 \%$, and total ash $-2.37 \%$. For the low fat pork sausage (T2), it was $50.63 \%$ (moisture), $23.87 \%$ (protein), $23.03 \%$ (fat) and $2.42 \%$ (total ash). Sensory parameters studied were indicating that low fat pork sausage (T2) was more acceptable to sensory panelists than the traditional pork sausage (T1) and low fat pork sausage (T2) was ranked very good throughout the storage period. Value added meat products may help to open new window to the snack food market in developing and under developed countries.
\end{abstract}

Keywords: Low fat pork sausage, traditional fat pork sausage, apple pulp, pomegranate seed

\section{Introduction}

In the World nearly two-thirds of the deaths that occurred in the global population were due to non-communicable diseases, mostly cardiovascular diseases (CVD), cancer, diabetes, and chronic lung disease (WHO, 2011) ${ }^{[16]}$. However, the incidence of these diseases can be reduced by changing behavioral risk factors (eg, tobacco and alcohol consumption) and by promoting a healthy diet and physical activity. Healthy and balanced diet provide different nutrients needed to meet metabolic requirements and are therefore important for proper nutrition (Olmedilla-Alonso et al., 2013) ${ }^{[11]}$. However, meat and meat products also contribute to the intake of fat, saturated fatty acids (SFA), cholesterol, salt, and other substances that can have negative health implications, depending on a variety of factors and pathophysiological circumstances. Thus, it is essential to be familiar with the composition, nutritional value, and health implications and the availability of different strategies to optimize the presence of bioactive compounds to produce healthier low fat pork sausage. Pork is considered to be an excellent source of B-complex vitamins. Meat products are poor source of fiber; fortification by using fiber rich fruits and fruits by-products may improve the fiber content of functional meat products. According to Dietary Guidelines for Americans (2010), dietary fibers are under consumed by most adults indicating that fiber fortification in meat products could have health benefits. Dietary fibers in meat products have other advantages such as fat replacement, increased water holding capacity and improved oxidative stability when the fiber source is associated with phenolic antioxidants (Choi et al., 2008). Apple and pomegranate seed are rich source of dietary fiber. Thus the use of dietary fiber for its technological properties and health benefits opens up interesting possibilities in functional meat product development (Verma and Banerjee, 2010) ${ }^{[14]}$. This dietary fiber has been added as a fat replacer and/or as a functional ingredient. These fruits derivatives rich in natural antioxidants (eg, flavonoids and phenolic compounds) have also been used to enhance the oxidative stability of pork sausages. These plant-derived compounds also have anti-inflammatory and anticancer activities and exhibit antimicrobial activity (Zhang et al., 2010) ${ }^{[18]}$. Different type's vegetable oils such as olive oil, cottonseed oil, corn, soybean, peanut, marine oils such as fish and algae, or combinations thereof, have been used to replace animal fat in meat products (Jimenez- Colmenero 
et al., 2015) ${ }^{[6]}$. Incorporation of healthier oils results in an acceleration of lipid oxidation reactions with reduction of shelf life and loss of sensorial and nutritional properties.

Ready to eat value added meat products are capturing the market due to the convenience as well as day-to-day fast lifestyle of today's world. At the same time consumers are equally aware of the food quality and safety related to human health. Hence, the meat industry is in continuous process of developing better meat products enriched with fibre and antioxidants along with a better shelf-life of the products. As we know, meat is zero fibre product, adding of fibres obviously add on to the quality of meat products. Low fat products that meet the nutritional criteria, taste expectations and convenience are at demand due to the changing lifestyle of the people nowadays. Pork can be a part of healthy diet. Processed meats are convenient but considered to be high fat foods. Therefore currently the focus has been given to employ various approaches for the reduction of fat in the formulation of meat products with acceptable flavor and texture. The microbial stability and safety of most traditional and novel foods is based on a combination of several factors (Mallika \& Prabhakar, 2011) ${ }^{[9]}$. The present study was undertaken to develop low fat and high fibre rich functional pork sausage through replacement of pork fat with olive oil, apple pulp and pomegranate seed powder. Their effect on the proximate composition and sensory qualities were studied.

\section{Materials and Methods}

Preparation of meat products: Pork meat was purchased from the freshly slaughtered Yorkshire pig carcasses of about 10 months to 1 year of age from the Aizawl market. The meat cuts were brought into laboratory in polyethylene bags and were trimmed off the external fat. The deboning of the cuts was carried out and back fat and other fats were separated from the lean meat. Meat was cut into uniform size in order to mince it. Natural casings were used for product making and casings were prepared in the laboratory from goat intestine. Edible olive oil was purchased from Aizawl market. Apple and pomegranate were purchased from the local market. Apple were washed properly, cut into thin slices and then dried in hot air oven at $70{ }^{\circ} \mathrm{C}$ for overnight. Likewise, pomegranate seeds were taken out and dried overnight in hot air oven at $70{ }^{\circ} \mathrm{C}$. Both the dried products were ground properly in a mixer grinder, sieved and kept in air tight containers for further use. External coverings of the onion and garlic were peeled off, weighed and taken in the ratio of $3: 1$. They were cut into smaller bits and blended into a fine paste and were used in the formulations. The spice-mix formula suggested by Hazarika (2005) ${ }^{[4]}$ was followed (Table 1). Spices were oven-dried at $50^{\circ} \mathrm{C}$ for $3 \mathrm{hrs}$. and were ground in a grinder and sieved through a fine mesh. The fine powder was weighed and taken into the required ratio for the preparation of the spice mixture, which was store in airtight container for further use.

Table 1: Composition of spice mixture

\begin{tabular}{|c|c|}
\hline Spice ingredients & Percent of mixture \\
\hline Anise seed (Soant) & 10 \\
\hline Black pepper (Kali mirch) & 5 \\
\hline Capsicum (Mirch) & 10 \\
\hline Caraway (Ajwain) & 10 \\
\hline Cardamom (Elaichi) & 4 \\
\hline Cinnamon (Dalchini) & 2 \\
\hline Cloves (Laung) & 15 \\
\hline Corriander (Dhania) & 20 \\
\hline Cumin (Zeera) & 10 \\
\hline Dry ginger (Sont) & 10 \\
\hline Turmeric (Haldi) & 100 \\
\hline Total &
\end{tabular}

Control and treatment pork sausages were prepared by using ingredients as presented in Table 2. Meat chunks and fat was minced in meat mincer. During mincing/chopping, the temperature was maintained around refrigeration temperature. Lean meat, pork fat, olive oil, dried apple pulp powder, dried pomegranate seed powder was added at various levels for different treatments during chopping of meat in bowl chopper along with other ingredients. The batter was transferred to stuffer for filling into natural casing; the encased mass was twisted and manually drawn together to form links and to form cylindrical loops. Sausages were cooked at $80^{\circ} \mathrm{C}$ for 20 minutes in water and smoked in an artificial smoking unit (Kerres Showsmoker CS 350 EL) for 20 minutes.

Table 2: Ingredients $\%$ for the preparation of control and treatment pork sausages

\begin{tabular}{|c|c|c|}
\hline Ingredients & T1 & T2 \\
\hline Pork lean meat & $80 \%$ & $80 \%$ \\
\hline Pork Fat & $10 \%$ & 0 \\
\hline Olive oil & 0 & $6 \%$ \\
\hline Dried apple pulp powder & 0 & $2 \%$ \\
\hline Dried pomegranate Seed powder & 0 & $2 \%$ \\
\hline Condiments (Onion and Garlic, 3:1) & $2.5 \%$ & $2.5 \%$ \\
\hline Dried spice mix & $1 \%$ & $1 \%$ \\
\hline Common Salt & $1.5 \%$ & $1.5 \%$ \\
\hline Ice water & $5 \%$ & $5 \%$ \\
\hline
\end{tabular}

Two treatments were prepared, namely, T1: Smoked pork sausage incorporated with $10 \%$ pork fat. Sausage batter was in the form of emulsion. T2: Smoked pork sausage incorporated with $6 \%$ olive oil, $2 \%$ of each dried apple pulp powder and pomegranate seed powder. Sausage batter was in the form of emulsion. The samples were aerobically packed and sealed in LDPE and kept under domestic refrigerator at $4 \pm 1{ }^{0} \mathrm{c}$ for 12 days and were analyzed for different physicochemical and sensory parameters at periodic intervals. 


\section{Physico-chemical parameters \\ Proximate composition}

Proximate composition, namely, moisture, protein, fat and total ash percent of samples were determined by standard methods described by AOAC (1995) ${ }^{[1]}$.

\section{Organoleptic evaluation Sensory evaluation}

A semi-trained taste panel consisting of faculty members and postgraduate students of department of livestock products technology evaluated the samples for the sensory attributes of appearance, flavour, texture, juiciness and overall acceptability using eight-point descriptive scale (Keeton, 1983) ${ }^{[8]}$, where $8=$ excellent and $1=$ extremely poor. The sensory evaluation room was air-conditioned at $20 \pm 2{ }^{\circ} \mathrm{C}$, with Relative Humidity (45-55) per cent and shadow-free illumination at (70-100) foot candles. The sensory evaluation was conducted late afternoon (Meilgaard et al., 2007) ${ }^{[10]}$. During evaluation, there was strict prohibition in interaction among panelists. The test samples were presented to the panelists after assigning the suitable codes. Samples were preheated in microwave and then serve to the panelists along with a glass of water to rinse their mouth on tasting the product samples.

\section{Statistical analysis}

Data were analyzed statistically on "SPSS-16.0" (SPSS Inc., Chicago, II USA) software package as per standard methods (Snedecor and Cochran, 1995) ${ }^{[12]}$. Duplicate samples were drawn for each parameter and the whole set of experiment was repeated three times to have $n=4$ observations for all parameters. The data were statistically analyzed by two-way ANOVA at the 5 per cent level $(p<0.05)$ and evaluated with Duncan's Multiple Range Test.

\section{Results and Discussion}

Proximate composition: Results in Table 3 showed the moisture content of traditional pork sausage (T1) and the low fat pork sausage (T2) were non-significant $(\mathrm{p}>0.05)$ difference during the storage period, but a significant $(p<$ $0.05)$ difference could be observed between T1 and T2. The higher moisture content of low fat pork sausage (T2) may be due to presence of apple pulp and pomegranate seed powder rich in fiber. Similar finding also recorded by Bose et al., (2010) ${ }^{[2]}$ that cracker biscuits treated with fiber rich chickpea husk as a result increased moisture content.

Protein content of low fat pork sausage (T1) was significantly $(P<0.05)$ lower than the traditional pork sausage $(\mathrm{T} 2)$, but a non-significant $(\mathrm{P}>0.05)$ change in protein (for both $\mathrm{T} 1$ and T2) were found during the storage period. Lower protein value of low fat pork sausage (T2) may be due to the presence of non-meat ingredients when compared with traditional pork sausage (T1). Similar finding were reported by Huang et al., (2011) ${ }^{[5]}$ incorporated with wheat fiber, oat fiber, and inulin in Chinese-style sausages.

Fat content of low fat pork sausage (T2) was significantly $(P<$ $0.05)$ lower than the traditional pork sausage (T1), but a nonsignificant $(\mathrm{P}>0.05)$ change in fat (for both $\mathrm{T} 1$ and $\mathrm{T} 2)$ were found during the storage. Lower fat value of low fat pork sausage (T2) may be due to pork fat replaced with olive oil, apple pulp and pomegranate seed powder. Similar findings also report by Thomas et al., (2016) ${ }^{[13]}$, where pork nuggets incorporating with Kordoi (Averrhoa carambola) fruit juice and bamboo (Bambusa polymorpha) shoot extract decrease the fat content.

A significantly higher $(P<0.05)$ total ash content was observed for low fat pork sausage (T2) as compared to traditional pork sausage (T1), it can be due to the use of apple pulp and pomegranate seed powder for preparation of pork sausage, but a non-significant $(\mathrm{P}>0.05)$ change in total ash (for both $\mathrm{T} 1$ and $\mathrm{T} 2$ ) were found during the storage. The findings of the present study that is increased total ash content is similar with the findings of Yadav et al., (2018) ${ }^{[17]}$ chicken sausages incorporated with wheat bran and dried carrot pomace resulted in the increase of total ash content.

Table 3: Proximate composition (\%) of pork sausage

\begin{tabular}{|c|c|c|c|c|c|c|c|c|}
\hline \multirow{2}{*}{ Days } & \multicolumn{2}{|c|}{ Moisture } & \multicolumn{2}{c|}{ Protein } & \multicolumn{2}{c|}{ Fat } & \multicolumn{2}{c|}{ Total ash } \\
\cline { 2 - 8 } & T1 & T2 & T1 & T2 & T1 & T2 & T1 & T2 \\
\hline $1^{\text {st }}$ & $47.91 \pm 0.038^{\mathrm{a}}$ & $50.63 \pm 0.013^{\mathrm{c}}$ & $24.72 \pm 0.015^{\mathrm{b}}$ & $23.87 \pm 0.018^{\mathrm{a}}$ & $25.18 \pm 0.004^{\mathrm{d}}$ & $23.03 \pm 0.006^{\mathrm{b}}$ & $2.37 \pm 0.004^{\mathrm{a}}$ & $2.42 \pm 0.006^{\mathrm{b}}$ \\
\hline $12^{\mathrm{th}}$ & $47.51 \pm 0.054^{\mathrm{a}}$ & $50.11 \pm 0.020^{\mathrm{c}}$ & $23.39 \pm 0.017^{\mathrm{d}}$ & $22.19 \pm 0.006^{\mathrm{a}}$ & $25.15 \pm 0.002^{\mathrm{d}}$ & $22.54 \pm 0.008^{\mathrm{b}}$ & $2.36 \pm 0.006^{\mathrm{b}}$ & $2.43 \pm 0.004^{\mathrm{c}}$ \\
\hline
\end{tabular}

Mean \pm S.E with different superscript(s) in a column differs significantly $(P<0.05),(n=4)$; T1: Smoked pork sausage incorporated with $10 \%$ pork fat. Sausage batter was in the form of emulsion, T2: Smoked pork sausage incorporated with $6 \%$ olive oil, $2 \%$ of each dried apple pulp powder and pomegranate seed powder. Sausage batter was in the form of emulsion.

\section{Sensory evaluation}

Table 4 showed the sensory evaluation parameters were analyzed at different interval from $1^{\text {st }}$ day to $12^{\text {th }}$ days. Sensory evaluation studies indicated that low fat pork sausage (T2) was preferred over traditional pork sausage (T1) for parameters like colour and appearance, flavour, texture and overall acceptability with a significant difference $(P<0.05)$, but juiciness significantly lower in case of low fat pork sausage (T1) compared to traditional pork sausage (T2) in $12^{\text {th }}$ day storage. Low fat pork sausage (T1) flavour intensity significantly higher $(P<0.05)$ score was observed as compare to traditional pork sausage (T2). The same trend was observed throughout the study period $\left(1^{\text {st }}, 5^{\text {th }}, 7^{\text {th }}, 10^{\text {th }}\right.$ and $12^{\text {th }}$ days $)$. Overall acceptability values indicated that low fat pork sausage (T1) had scored highest score in between very good and extremely acceptable whereas traditional pork sausage (T2) in between good/moderately acceptable to very much acceptable. Similar findings also recorded by the Verma et al., (2010) ${ }^{[15]}$ in low fat chicken nuggets treated with apple pulp and Kaur et al., (2015) ${ }^{[7]}$ in chicken nuggets treated with pomegranate seed, grapes seed and tomato powders.

Table 4: Sensory evaluation of pork sausage

\begin{tabular}{|c|c|c|c|c|c|c|}
\hline & & $\mathbf{1}^{\text {st }}$ day & $\mathbf{5}^{\text {th }} \mathbf{d a y}$ & $\mathbf{7}^{\text {th }}$ day & $\mathbf{1 0}^{\text {th }}$ day & $\mathbf{1 2}^{\text {th }}$ day \\
\hline \multirow{2}{*}{ Colour and appearance } & $\mathrm{T} 1$ & $6.76 \pm 0.006^{\mathrm{aAA}}$ & $6.73 \pm 0.006^{\mathrm{abB}}$ & $6.50 \pm 0.006^{\mathrm{aAB}}$ & $6.40 \pm 0.006^{\mathrm{aC}}$ & $6.30 \pm 0.010^{\mathrm{aD}}$ \\
\cline { 2 - 7 } & $\mathrm{T} 2$ & $6.95 \pm 0.006^{\mathrm{abA}}$ & $6.90 \pm 0.006^{\mathrm{CB}}$ & $6.80 \pm 0.006^{\mathrm{bAB}}$ & $6.78 \pm 0.004^{\mathrm{bC}}$ & $6.75 \pm 0.006^{\mathrm{bD}}$ \\
\hline
\end{tabular}




\begin{tabular}{|c|c|c|c|c|c|c|}
\hline \multirow{2}{*}{ Flavour } & $\mathrm{T} 1$ & $6.65 \pm 0.006^{\mathrm{abA}}$ & $6.58 \pm 0.004^{\mathrm{abB}}$ & $6.50 \pm 0.006^{\mathrm{abAB}}$ & $6.40 \pm 0.006^{\mathrm{abC}}$ & $6.30 \pm 0.010^{\mathrm{abD}}$ \\
\cline { 2 - 6 } & $\mathrm{T} 2$ & $7.23 \pm 0.008^{\mathrm{bA}}$ & $6.90 \pm 0.003^{\mathrm{bB}}$ & $6.78 \pm 0.004^{\mathrm{bAB}}$ & $6.70 \pm 0.008^{\mathrm{bC}}$ & $6.65 \pm 0.008^{\mathrm{bD}}$ \\
\hline \multirow{2}{*}{ Texture } & $\mathrm{T} 1$ & $6.45 \pm 0.006^{\mathrm{aA}}$ & $6.40 \pm 0.010^{\mathrm{aAB}}$ & $6.38 \pm 0.006^{\mathrm{aAB}}$ & $6.36 \pm 0.008^{\mathrm{bAB}}$ & $6.30 \pm 0.006^{\mathrm{aB}}$ \\
\cline { 2 - 6 } & $\mathrm{T} 2$ & $6.91 \pm 0.008^{\mathrm{abA}}$ & $6.88 \pm 0.004^{\mathrm{cAB}}$ & $6.75 \pm 0.006^{\mathrm{abAB}}$ & $6.70 \pm 0.008^{\mathrm{cB}}$ & $6.62 \pm 0.047^{\mathrm{bC}}$ \\
\hline \multirow{2}{*}{ Juiciness } & $\mathrm{T} 1$ & $6.98 \pm 0.004^{\mathrm{abA}}$ & $6.75 \pm 0.006^{\mathrm{aAB}}$ & $6.68 \pm 0.006^{\mathrm{abAB}}$ & $6.62 \pm 0.006^{\mathrm{abAB}}$ & $6.58 \pm 0.009^{\mathrm{aB}}$ \\
\cline { 2 - 7 } & $\mathrm{T} 2$ & $7.05 \pm 0.028^{\mathrm{abA}}$ & $6.76 \pm 0.008^{\mathrm{cB}}$ & $6.60 \pm 0.008^{\mathrm{abAB}}$ & $6.55 \pm 0.004^{\mathrm{abC}}$ & $6.50 \pm 0.008^{\mathrm{bD}}$ \\
\hline \multirow{2}{*}{ Overall acceptability } & $\mathrm{T} 1$ & $6.73 \pm 0.006^{\mathrm{abA}}$ & $6.70 \pm 0.008^{\mathrm{abAB}}$ & $6.50 \pm 0.008^{\mathrm{abB}}$ & $6.20 \pm 0.008^{\mathrm{abC}}$ & $6.04 \pm 0.032^{\mathrm{ab}}$ \\
\cline { 2 - 7 } & $\mathrm{T} 2$ & $7.18 \pm 0.008^{\mathrm{bA}}$ & $7.10 \pm 0.006^{\mathrm{aB}}$ & $7.06 \pm 0.006^{\mathrm{aAB}}$ & $7.03 \pm 0.002^{\mathrm{bC}}$ & $7.01 \pm 0.006^{\mathrm{bD}}$ \\
\hline
\end{tabular}

Mean \pm S.E with different single capital letter superscript(s) in a column differ significantly $(P<0.05),(n=4)$; T1: Smoked pork sausage incorporated with $10 \%$ pork fat. Sausage batter was in the form of emulsion, T2: Smoked pork sausage incorporated with $6 \%$ olive oil, $2 \%$ of each dried apple pulp powder and pomegranate seed powder. Sausage batter was in the form of emulsion.

\section{Conclusion}

Low fat pork sausage (T1) could be manufactured with olive oil and without added animal fat. The low-fat pork sausage would be highly desirable from a diet/health standpoint as they contain monounsaturated vegetable oil, have lower caloric value, reduced cholesterol and higher protein content. Storage studies conducted indicated that proximate composition is not affected at $4 \pm 1{ }^{\circ} \mathrm{C}$ for 12 days domestic refrigeration storage. Sensory attributes of low fat pork sausage were rated in between extremely acceptable to very good. Ready to eat pork based functional snacks are a good alternative to junk foods which are currently dominating the snack food industry. Meat products may help to open new window to the snack food market in developing and under developed countries.

\section{Acknowledgement}

I am grateful to the Dean of this Institute and Head of Animal Nutrition Department for providing necessary facilities to conduct this experiment and to $\mathrm{Mr}$. Vanlalfinga and $\mathrm{Mr}$. Rajesh for their technical help.

\section{References}

1. AOAC. Official methods of Analysis, $16^{\text {th }}$ Edn., Association of Official Analytical Chemists, Washington, DC 1995.

2. Bose D, Shams-Ud-Din M. The effect of chickpea (Cicer arietinim) husk on the properties of cracker biscuits. Journal of the Bangladesh Agricultural University 2010,8(452-2016-35753).

3. Choi YS, Choi JH, Han DJ, Kim HY, Lee MA, Lee ES et al. Effects of rice bran fiber on quality of low-fat tteokgalbi. Food Science and Biotechnology 2008;17(5):959-964.

4. Hazarika P. Studies on value added poultry products from heavy weight broilers, Ph.D thesis, submitted to Indian Veterinary Research Institute, Izatnagar, U.P., India 2005.

5. Huang SC, Tsai YF, Chen CM. Effects of wheat fiber, oat fiber, and inulin on sensory and physico-chemical properties of Chinese-style sausages. Asian-Australasian J. Anim. Sci 2011;24(6):875-880.

6. Jimenez-Colmenero F, Salcedo-Sandoval L, Bou R, Cofrades S, Herrero AM, Ruiz-Capillas C. Novel applications of oil-structuring methods as a strategy to improve the fat content of meat products. Trends in Food Science \& Technology 2015;44(2):177-188.
7. Kaur S, Kumar S, Bhat ZF, Kumar A. Effect of pomegranate seed powder, grape seed extract and tomato powder on the quality characteristics of chicken nuggets. Nutrition \& Food Science 2015.

8. Keeton JT. Effects of fat and $\mathrm{NaCl} /$ phosphate levels on the chemical and sensory properties of pork patties. J. Food Sci 1983;48(3):878-881.

9. Mallika EN, Prabhakar K. Effect of Hurdles on the Quality of Low Fat Pork Sausages in Storage. Vet Scan | Online Veterinary Medical Journal 2011;6(2):98-98.

10. Meilgaard MC, Civille GV, Carr BT. Sensory Evaluation Techniques, $4^{\text {th }}$ ed., CRC Press, Boca Raton, FL 2007,31$35 \mathrm{p}$.

11. Olmedilla-Alonso B, Jiménez-Colmenero F, SánchezMuniz FJ. Development and assessment of healthy properties of meat and meat products designed as functional foods. Meat Sci 2013;95:919-930.

12. Snedecor GW, Cochran WG. In: Statistical Methods. $8^{\text {th }}$ edn, Oxford and IBH Pub. Cp. New Delhi 1995.

13. Thomas R, Jebin N, Saha R, Sarma DK. Antioxidant and antimicrobial effects of kordoi (Averrhoa carambola) fruit juice and bamboo (Bambusa polymorpha) shoot extract in pork nuggets. Food Chem 2016;190:41-49.

14. Verma AK, Banerjee R. Dietary fibre as functional ingredient in meat products: a novel approach for healthy living - a review. Journal of Food Science and Technology-Mysore 2010;47:247-257.

15. Verma AK, Sharma BD, Banerjee R. Effect of sodium chloride replacement and apple pulp inclusion on the physico-chemical, textural and sensory properties of low fat chicken nuggets. LWT- Food Sci. Technol 2010;43(4):715-719.

16. WHO. Global Status Report on Non-communicable Diseases 2010. WHO Library Cataloguing-in-Publication Data, Geneva, Switzerland 2011.

17. Yadav S, Pathera AK, Islam RU, Malik AK, Sharma DP. Effect of wheat bran and dried carrot pomace addition on quality characteristics of chicken sausage. AsianAustralasian J. Anim. Sci 2018;31(5):729.

18. Zhang W, Xiao S, Samaraweera H, Lee EJ, Ahn DU. Improving functional value of meat products. Meat Sci 2010;86:15-31. 